\title{
SOFTWARE APLIKASI PEMBUAT ANIMASI SEBAGAI ALTERNATIF PENGGANTI ALAT PERAGA UNTUK MENANAMKAN KONSEP DASAR MATEMATIKA
}

\author{
Asnurul Isroqmi \\ Universitas PGRI Palembang \\ asnurul@gmail.com
}

\begin{abstract}
ABSTRAK
Matematika merupakan ilmu dasar yang menjadi alat untuk mempelajari ilmu pengetahuan yang lain. Penguasaan terhadap konsep matematika dasar yang umumnya sudah diberikan sejak di sekolah dasar mutlak diperlukan. Penyajian ke siswa diperlukan kecermatan yang baik, agar siswa memiliki kemampuan secara benar untuk memahami konsep-konsep dasar matematika, untuk dibawa selanjutnya ke jenjang pendidikan yang lebih tinggi. Alat peraga dapat digunakan untuk menyajikan konsep dengan baik, namun dengan berbagai kelemahan terutama dalam berinovasi pada pembelajaran di kelas, maka perlu alat pembelajaran yang lain sebagai alternatif untuk menggantikan alat peraga. Kajian ini bertujuan untuk membahas software aplikasi yang dapat digunakan untuk membuat media pembelajaran berbentuk animasi sebagai alternatif pengganti alat peraga, dan kriteria pemilihan software aplikasi agar dapat dikuasai oleh guru.
\end{abstract}

Kata kunci : pemahaman konsep dasar, software aplikasi

\begin{abstract}
Mathematics is a basic science that is a tool for learning other sciences. Mastery of basic mathematical concepts that have generally been given since elementary school is necessary. Presentation of it to students requires good accuracy so that students can understand the basic concepts of mathematics correctly to be brought to the next level of higher education. Teaching aids can be used to present concepts well. However, with various weaknesses, especially in innovating learning in class, it is necessary to use other instructional media as an alternative to replacing teaching aids. This study aims to discuss the application software that can be used to create instructional media in the form of animation, as an alternative to substitute teaching aids, and the criteria to select application software to be mastered by the teacher.
\end{abstract}

Keywords : understanding basic concepts, application software 


\section{PENDAHULUAN}

Kegiatan belajar mengajar merupakan suatu hal yang tidak dapat dilepaskan dari proses pendidikan. Dan kegiatan belajar sangat ditentukan oleh guru dan siswa itu sendiri, terutama oleh guru sebagai pendidik. Guru tidak hanya dituntut untuk dapat menguasai materi dengan baik, tapi juga mampu menyajikan materi yang diajarkan dengan lebih optimal. Guru tidak hanya dituntut untuk dapat menguasai berbagai metode atau pendekatan pembelajaran, namun juga perlu kreativitas atau ide-ide baru untuk dapat mengembangkan pembelajaran di sekolah, terutama dalam proses pembelajaran pada pemahaman konsep-konsep dasar pada semua mata pelajaran.

Pemahaman atau penanaman konsep-konsep dasar perlu menjadi perhatian yang sangat serius terutama konsep-konsep dasar matematika yang memerlukan pemahaman logika berpikir atau penalaran, dimana diantaranya konsep-konsep dasar tersebut hanya efektif dapat disampaikan melalui peragaan.

Somayasa, Natajaya, dan Candiasa (2013 : 2) menyatakan bahwa “...kondisi pembelajaran yang masih banyak dilakukan guru adalah menekankan materi yang dibebani kepada siswa, sehingga cenderung hanya menghafal konsep-konsep matematika, tanpa memahami proses pemahaman makna dibalik konsep yang dipelajari". Kemudian Maharani (2017 : 4) menyatakan bahwa “... masalah yang paling sering muncul selama pembelajaran di tingkat sekolah dasar adalah pada pembelajaran mengenai konsep-konsep matematika. Pembelajaran yang sudah dilakukan masih belum mendorong siswa untuk menguasai suatu konsep matematika tertentu, khususnya konsep perkalian dan pembagian. Lemahnya konsep perkalian dan pembagian masih sering ditemui ketika siswa sudah melanjutkan ke jenjang kelas berikutnya maupun jenjang sekolah menengah".

Prihandoko (2006:a1) berpendapat bahwa matematika merupakan ilmu dasar yang menjadi alat untuk mempelajari ilmu pengetahuan yang lain, oleh karenanya penguasaan terhadap matematika menjadi mutlak diperlukan. Konsep-konsep matematika sejak dini sudah harus dipahami dengan benar. Konsep matematika yang paling dasar yang sudah harus diberikan pada siswa sejak dini umumnya di sekolah dasar (SD) terlihat sederhana dan mudah, tetapi karena memuat konsep-konsep dasar yang sangat penting maka hal ini tidak boleh dipandang sepele. Dalam menyajikan konsep-konsep tersebut diperlukan kecermatan yang baik, sehingga siswa memiliki kemampuan secara benar untuk memahami konsep-konsep dasar matematika, hal ini karena kesan dan pandangan yang diterima siswa terhadap suatu konsep terutama di sekolah dasar dapat terbawa selanjutnya ke jenjang pendidikan berikutnya.

Sebagai contoh mengenai konsep pembagian bilangan, menurut Simanjuntak, dkk (1990 : 130), membagi merupakan pengerjaan mengurang berulang dengan pengurang tetap. Pengurangan yang tetap yang dimaksud adalah nilai pembagi itu sendiri. Secara ringkas pembagian adalah pengurangan berulang. Dengan demikian ketika guru harus menerangkan hasil dari pembagian dari $6: 2$ adalah dengan cara mengurangkan angka 6 tersebut dengan 2 beberapa kali, $6-2-2-2=0$, jumlah pengurangan yang dilakuan itulah hasil dari pembagian tersebut. Untuk contoh yang lain, misalnya $2: 1 / 2$, merupakan hasil dari $2-1 / 2-1 / 2-1 / 2-1 / 2=0$.

Konsep-konsep dasar seperti ini harus sudah ditanamkan kepada siswa sejak dini, agar mereka tidak menjadi kebingungan ketika ada pernyataan ada 6 buah apel harus dibagi 2, apakah 6 apel tersebut dibuat menjadi 2 bagian sehingga tiap bagian memperoleh 3 apel, atau buah apel tersebut dikurangi atau dibuat setiap bagian 
menjadi 2 sehingga diperoleh 3 bagian dimana setiap bagian ada 2 apel. Demikian juga halnya $2: 1 / 2$, apakah 2 apel dibuat menjadi $1 / 2$ bagian, ini menjadi rancu, atau 2 apel tersebut dibuat menjadi bagian lain dimana setiap bagian adalah $1 / 2$ sehingga diperoleh 4 bagian apel, dimana setiap bagian apel adalah $1 / 2$.

Kebingungan atau kerancuan hal seperti ini masih banyak dijumpai, sebagai akibat penanaman konsep dasar matematika yang disampaikan oleh guru yang keliru. Namun demikian ketika pemahaman konsep oleh guru sudah benar, permasalahan selanjutnya adalah bagaimana menyampaikan atau menanamkan konsep dasar matematika tersebut kepada siswa, sehingga siswa dapat memahami konsep-konsep dasar itu dengan benar.

Alat peraga atau berbagai software aplikasi komputer merupakan solusi, sebagai alat pembelajaran untuk menyampaikan sekaligus memperagakan konsepkonsep dasar matematika yang perlu ditanamkan kepada siswa. Namun dengan memperhatikan keunggulan dan kekurangan dari kedua alat pembelajaran tersebut, maka dapat saja keduanya digunakan dan bisa jadi pula salah satu dari keduanya menjadi alternatif pengganti yang lainnya.

Di era digital saat ini, maka software aplikasi komputer dengan berbagai keunggulan yang dimiliki dapat menjadi pembuat media pembelajaran yang efektif yang juga dapat menjadi alternatif sebagai pengganti alat peraga dalam menyampaikan konsep-konsep dasar matematika. Namun permasalahan berikutnya adalah bagaimana penguasaan guru atau pendidik terhadap software aplikasi, sehingga tidak begitu memiliki kendala dalam memanfaatkan fasilitas yang tersedia untuk memperagakan konsep-konsep pelajaran terutama konsep-konsep dasar matematika, layaknya pembelajaran menggunakan alat peraga.

\section{PEMBAHASAN}

\section{Pemahaman konsep}

Konsep dapat diartikan sebagai suatu ide abstrak yang bisa digunakan untuk menggolongkan sekumpulan objek (Depdiknas, 2003: 18). Menurut Sagala (2008), konsep merupakan suatu ide abstraksi yang mewakili objek-objek, kejadian-kejadian, kegiatan-kegiatan, atau hubungan-hubungan yang mempunyai atribut-atribut yang sama. Dan pengertian konsep dalam matematika dinyatakan oleh Gagne (Ruseffendi, 2006 : 97) sebagai ide abstrak yang memungkinkan kita mengelompokkan objekobjek ke dalam contoh dan bukan contoh.

Sedangkan pengertian pemahaman itu sendiri diartikan beberapa pendapat berikut ini. Sardiman (2010 : 43), pemahaman adalah menguasai sesuatu dengan pikiran. Menurut Purwanto (Murizal, 2012:19) bahwa pemahaman merupakan tingkat kemampuan yang diharapkan ada pada siswa yaitu mampu memahami arti atau konsep, situasi, atau fakta yang diketahuinya. Sedangkan Soedjadi (2000:14), mengartikan konsep ke dalam bentuk atau suatu yang abstrak untuk melakukan penggolongan yang nantinya akan dinyatakan ke dalam suatu istilah tertentu.

Dalam pembelajaran matematika pemahaman konsep matematika merupakan salah satu tujuan yang sangat penting, agar mahasiswa dapat lebih mengerti akan konsep materi pelajaran itu sendiri. Hal ini sesuai dengan pernyataan bahwa tiga aspek dari kemampuan dalam belajar matematika, yaitu pemahaman konsep, penalaran dan komunikasi, dan pemecahan masalah (Andesta, dkk, 2013).

Sejalan dengan hal di atas, Depdiknas (2003 : 2) juga menyatakan, salah satu kemahiran atau kecakapan yang diharapkan dapat tercapai oleh para siswa dalam 
pembelajaran matematika adalah pemahaman konsep, yaitu menunjukkan pemahaman konsep matematika yang dipelajarinya, menjelaskan keterkaitan antar konsep dan mengaplikasikan konsep atau algoritma secara luwes, akurat, efisien, dan tepat dalam pemecahan masalah.

Kemudian kaitan matematika terhadap penalaran atau penggunaan logika, Ruseffendi (2006) menyatakan bahwa matematika terbentuk sebagai hasil pemikiran manusia yang berhubungan dengan ide, proses, dan penalaran. Dan Shadiq (2004 : 3) menyatakan bahwa materi matematika dan penalaran matematika merupakan dua hal yang tidak dapat dipisahkan, yaitu materi matematika dipahami melalui penalaran dan penalaran dipahami dan dilatih melalui belajar materi matematika.

Dengan demikian maka pemahaman konsep dalam matematika tidak lepas dari penalaran atau penggunaan logika. Keterkaitan antar objek bahkan antar konsep, perlu dikuasai dan dipahami dengan daya nalar atau berpikir logis siswa. Hal ini sejalan dengan apa yang dinyatakan oleh Gosev dan Safuanov (Dahlan, 2004 : 2), dalam suatu proses kegiatan berpikir memerlukan pemahaman terhadap masalah yang berhubungan dengan materi yang sedang dipikirkan, kemampuan dalam bernalar (reason), kemampuan intelektual, imajinasi, dan keluwesan (fleksibilitas) dari pikiran yang merentang kedalam hasil pemikiran.

Bagaimana perlunya penanaman konsep dasar ini pada siswa, Prihandoko (2006 : a1) menyatakan bahwa matematika merupakan ilmu dasar yang menjadi alat untuk mempelajari ilmu pengetahuan yang lain, oleh karenanya penguasaan terhadap matematika menjadi mutlak diperlukan. Lebih lanjut dinyatakan Prihandoko (2006 : a2) bahwa pemahaman suatu konsep matematika secara benar mutlak diperlukan oleh seorang guru atau calon guru sebelum mereka mulai mengajarkan pada siswanya.

Uraian di atas memperlihatkan bagaimana berbagai pemahaman konsep perlu ditanamkan sejak dini, terutama konsep dasar matematika yang memerlukan penalaran atau penggunaan logika. Dan guru sebagai pendidik yang berkewajiban memberikan konsep-konsep dasar tersebut yang harus menyajikan dengan membangkitkan daya nalar siswa bahkan harus menjelaskan keterkaitan antar objek dan antar konsep, maka sangat diperlukan peragaan atau pengaplikasian konsep. Dan pengaplikasian konsep terutama dalam proses pembelajaran di kelas diperlukan alat pembelajaran baik alat peraga atau media pembelajaran lainnya.

\section{Pengaplikasian konsep dan alat peraga}

Dalam matematika daya nalar atau berpikir logis jauh lebih dominan digunakan dibandingkan dengan menghapal. Seperti apa yang dinyatakan oleh Sutawidjaja dan Afgani (2011 : 13), matematika bersifat aksiomatika, abstrak, deduktif, dan simbolik. Unsur-unsurnya saling berkaitan satu sama lain, sehingga tidak dapat dipelajari dengan cara menghafal saja. Hafal harus didasari dengan pemahaman, karena hafal belum tentu berarti paham demikian juga sebaliknya paham belum tentu hafal.

Seperti contoh konsep matematika yang dibahas sebelumnya, yaitu mengenai konsep pembagian bilangan. Operasi hitung pembagian $6: 2$, adalah seperti halnya pengurangan berulang bilangan 6 dengan bilangan tetap 2 sampai menghasilkan nilai 0 , sehingga diperoleh $6-2-2-2=0$. Konsep semacam ini memerlukan pemahaman dengan kemampuan penalaran atau berpikir logis tanpa perlu menghafal. Dan untuk memahami konsep-konsep semacam ini memerlukan peragaan atau pengaplikasian konsep itu sendiri untuk memperlihatkan hubungan antara pembagian 
dan pengurangan, karena hubungan ini tidak dapat dijelaskan dengan pembuktian rumus atau penyelesaian masalah. Dengan peragaan siswa dapat memahami dengan baik dan tidak timbul kesalahpahaman atau salah mengerti. Effendi, dkk (2007 : 86), menyatakan bahwa pada tahap pemahaman suatu konsep matematika yang abstrak, dapat ditingkatkan dengan mewujudkan konsep tersebut dalam amalan pengajaran.

Untuk dapat memperagakan atau mengaplikasikan konsep dalam pembelajaran di kelas diperlukan alat peraga atau media. Fungsi penggunaan media pembelajaran adalah memudahkan siswa dalam memahami konsep yang abstrak, membantu guru dalam mengajar dan memberikan pengalaman yang lebih nyata (Asnawir dan Usman, 2002 : 27). Dan menurut Nasution (2003 : 100) alat peraga adalah alat pembantu dalam mengajar agar lebih efektif.

Contoh konsep pembagian di atas, dari pengoperasian hitung bilangan $6: 2$, yang merupakan pengurangan berulang dari bilangan 6 dengan bilangan tetap 2, bisa diperagakan dengan menggunakan 6 kelereng atau bola yang diletakkan pada sebuah wadah keranjang, kemudian keenam kelereng tersebut diambil dua-dua (setiap pengambilan 2 kelereng) untuk diletakkan ke wadah lain. Setelah kelereng di keranjang habis, lalu dihitung berapa jumlah kelompok atau bagian di wadah lain tersebut. Maka dengan demikian diperoleh hasilnya adalah 3 bagian, sehingga konsep pembagian yang benar dari $6: 2$ adalah membuat bilangan yang dibagi (6) diubah menjadi bagian-bagian lain yang sesuai dengan nilai pembaginya (2). Dan menjadi keliru bila dinyatakan bahwa $6: 2$ adalah membuat jumlah yang 6 menjadi 2 bagian, dijadikan setiap bagian adalah 3 .

Contoh lain yang memerlukan peragaan lebih jauh lagi, misalnya operasi hitung dari 2 : $1 / 2$, dalam kasus ini tidak hanya konsep pembagian yang perlu diperhatikan tapi juga konsep bilangan pecahan itu sendiri. Selama ini banyak guru menjelaskan pembagian seperti itu cukup mengubah operasi pembagian menjadi perkalian kemudian bilangan pecahan dibalik, yaitu $2: 1 / 2$ diperoleh dengan $2 \times 2 / 1$ tanpa pernah memberikan konsepnya dengan benar. Dan peragaan untuk membagi operasi hitung dari bilangan bulat ke bilangan pecahan, tidak dapat lagi menggunakan kelereng, karena guru memerlukan alat peraga yang bisa dipotong menjadi 2 bagian untuk menunjukkan bilangan yang bernilai $1 / 2$. Alat peraga yang bisa digunakan sehingga bisa dipotong menjadi dua bagian bisa saja menggunakan kertas atau bahan lainnya, untuk menunjukkan nilai $1 / 2$ adalah 1 bagian kertas yang dipotong menjadi 2 bagian dengan ukuran yang sama besar.

\section{Software aplikasi alternatif pengganti alat peraga}

Kelereng yang digunakan pada kasus di atas merupakan alat peraga, karena fungsinya yang bisa digunakan membantu proses pembelajaran untuk menerangkan/mewujudkan dari suatu konsep. Menurut Ali (Sundayana, 2016:7), alat peraga adalah segala sesuatu yang dapat digunakan untuk menyatakan pesan merangsang pikiran, perasaan, dan perhatian dan kemauan peserta didik sehingga dapat mendorong proses belajar. Anderson (Lestari, 2006:2), menyatakan bahwa alat peraga digunakan sebagai media untuk membantu para pengajar. Kemudian Ruiz dkk. (Asyhar, 2011:11) berpendapat bahwa alat peraga dapat digunakan oleh guru untuk memberi penekanan pada informasi, memberikan stimulasi perhatian, dan memfasilitasi proses pembelajaran. Sedangkan alat peraga matematika itu sendiri menurut Pramudjono (Sundayana, 2016:7), adalah benda konkret yang dibuat, 
kemudian disusun dengan sengaja yang digunakan untuk membantu menanamkan atau mengembangkan konsep matematika.

Dari berbagai pengertian di atas maka dapat dinyatakan fungsi alat peraga pada pembelajaran matematika yaitu agar konsep matematika yang bersifat abstrak menjadi kongkrit dan mudah dipahami.

Berbagai keuntungan dan kelebihan dalam proses pembelajaran dengan memanfaatkan alat peraga, namun demikian alat peraga memerlukan guru atau pendidik dalam penggunaannya pada proses pembelajaran, karena sifatnya yang hanya sebagai alat bantu. Selain itu pula alat peraga terkadang perlu di desain khusus dalam pembuatannya sehingga memerlukan waktu yang lama kemudian sulit untuk dimodifikasi untuk pembelajaran materi atau konsep lain. Dan menjadi kendala pula ketika alat peraga harus dibawa berpindah-pindah tempat, karena terkadang jumlah yang banyak dan ukuran yang besar.

Keterbatasan alat peraga seperti hal di atas, menjadikan hambatan bagi guru dalam berinovasi pada proses pembelajaran. Guru kesulitan untuk memperagakan konsep matematika yang sedikit berbeda atau sama namun dengan contoh yang lain, hal ini disebabkan guru harus berpindah dari satu alat peraga ke alat peraga lain, merubah alat peraga yang sudah didesain sedemikian rupa, bahkan untuk memodifikasi sedikit perubahan pada alat peraga.

Terdapat alat pembelajaran lain yang dapat digunakan dalam proses pembelajaran. Salah satunya adalah dengan memanfaatkan software aplikasi komputer tertentu untuk mendesain media pembelajaran berbentuk animasi. Penggunaan alat pembelajaran berupa animasi komputer dapat mengatasi permasalahan-permasalahan pada alat peraga seperti yang diuraikan di atas, karena mengganti peragaan konsep-konsep dasar matematika atau memberikan contohcontoh penerapan lainnya tidaklah sulit untuk dilakukan, karena untuk memodifikasi desain cukup hanya dengan membuka kembali software aplikasi komputer yang digunakan.

Animasi komputer yang dirancang dengan menggunakan software aplikasi komputer dapat disebut sebagai media pembelajaran berbentuk animasi. Terdapat perbedaan antara alat peraga dan media pembelajaran. Menurut Asnawir dan Usman (2002) “....perbedaan antar media dengan alat peraga terletak pada fungsi, bukan substansinya saja. Sumber belajar dikatakan alat peraga jika hal tersebut fungsinya hanya sebagai alat bantu. Hal tersebut dikatakan media jika sumber belajar itu merupakan bagian yang integral dari seluruh kegiatan belajar"

Letak perbedaannya adalah peran guru jika media pembelajaran dirancang untuk bisa saja digunakan oleh si peserta didik atau siswa langsung tanpa dibantu oleh guru atau pendidik, sedangkan alat peraga membutuhkan guru atau pendidik untuk penggunaannya karena fungsinya sebagai alat bantu mengajar

Peragaan pembagian menggunakan kelereng untuk contoh di atas atau diganti dengan objek lain misalnya bola, desain media pembelajaran berbentuk animasi dengan menggunakan software aplikasi komputer dapat dirancang sedemikian rupa sampai pada gerakan animasi bola berpindah dari satu wadah ke wadah lainnya.

Pada contoh konsep pembagian $6: 2$, desain gambar objek dan gerakan animasi dapat dilihat pada gambar berikut ini. Gerakan animasi pantulan bola dari ember ke wadah lain dibuat sedemikian rupa, sehingga menarik perhatian siswa. 

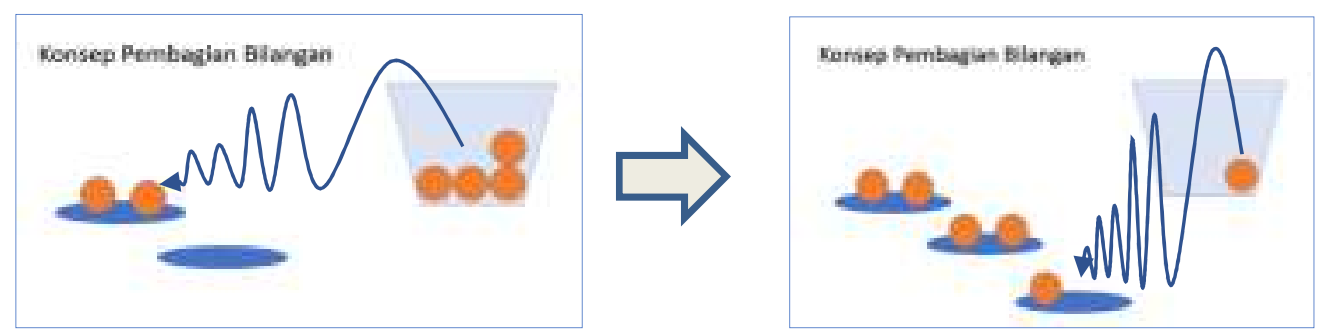

Gambar 1. Desain animasi gerakan bola keluar dari ember ke wadah lain untuk memperagakan konsep pembagian bilangan

Dengan gerakan 6 bola dari ember ke posisi tiga wadah lainnya seperti gambar di atas, menanamkan pemahaman konsep pembagian, bahwa pembagian adalah pengurangan dengan bilangan tetap dan dengan contoh pembagian contoh operasi hitung $6: 2$ artinya adalah membuat keenam bola tersebut dibuat menjadi dua-dua pada setiap wadah, setiap bagian terdapat 2 bola. Bukan membuat ke enam bola tersebut di bagi menjadi 2, sehingga ada dua bagian/wadah yang berisi 3 bola.

Demikian juga untuk contoh $2: 1 / 2$, dapat pula didesain seperti halnya di atas. Namun, siswa diberikan dahulu pemahaman konsep bilangan pecahan, misalnya menggambarkan kertas yang dipotong 2 , sehingga setiap bagian menjadi $1 / 2$, seperti gambar berikut ini.

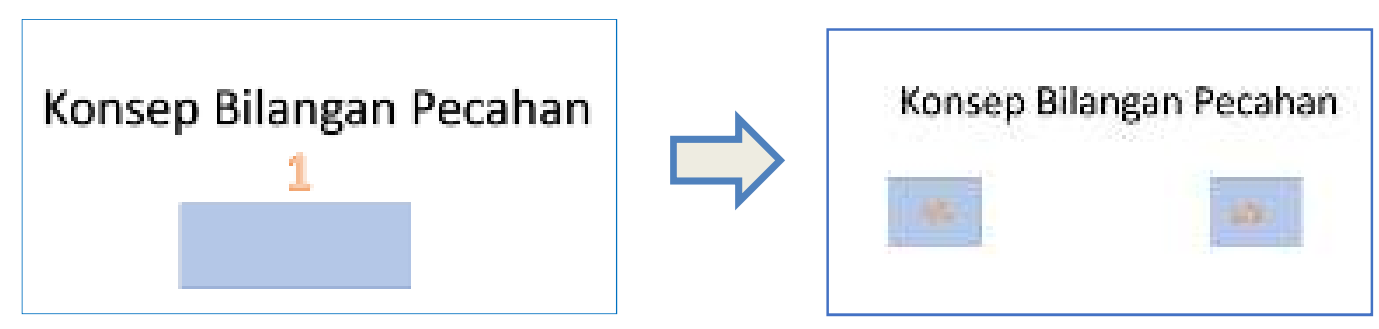

Gambar 2. Desain animasi untuk menggambarkan konsep bilangan pecahan 1/2

Awalnya kertas adalah bernilai 1, kemudian setelah dipotong dengan sama besar maka setiap bagian adalah $1 / 2$.

Kemudian untuk contoh konsep pembagian operasi hitung dari 2 : 1/2 diperlihatkan sebagai berikut.

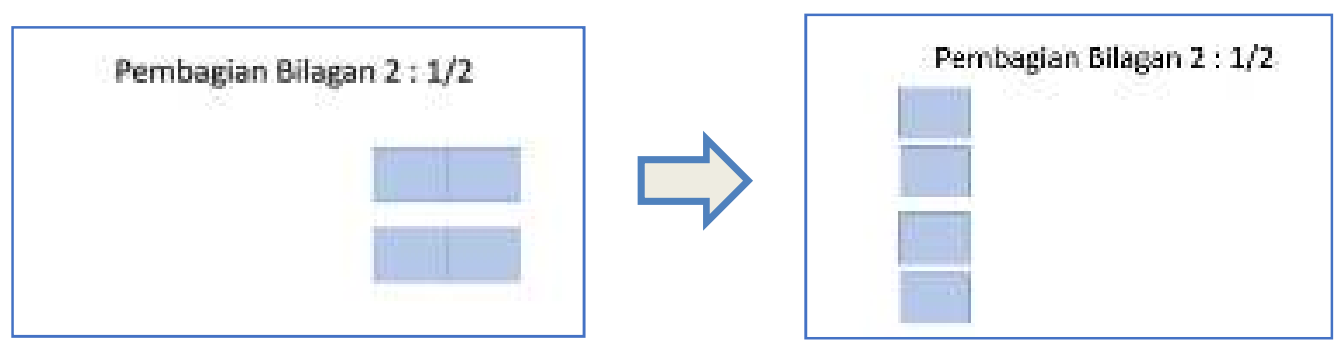

Gambar 3. Desain animasi untuk memperlihatkan konsep pembagian dari $2: 1 / 2$ 
Melalui animasi peragaan yang dicontohkan di atas, dapat ditanamkan konsep kepada siswa mengapa sesungguhnya pembagian dengan bilangan pecahan sama saja halnya melakukan perkalian dengan membalik bilangan pecahan pembagi. Artinya operasi hitung dari $2: 1 / 2$ sama saja dengan $2 \times 2 / 1$, karena setiap bilangan yang dibagi dibuat menjadi beberapa bagian sesuai nilai pecahan itu sendiri. Operasi hitung dari $2: 1 / 2$, memberikan pengertian bahwa membagi dengan pembagi $1 / 2$ adalah membuat nilai 1 menjadi menjadi 2 bagian, karena ada 2 kertas dan setiap kertas dibuat menjadi 2 bagian, maka diperoleh semuanya menjadi 4 bagian kertas, dimana setiap bagian adalah $1 / 2$ kertas. Sehingga diperoleh hasilnya adalah 4 . Itulah sebabnya mengapa $2: 1 / 2$ sama dengan halnya $2 \times 2 / 1$.

Konsep-konsep dasar matematika yang disampaikan oleh guru dengan menggunakan media pembelajaran berbentuk animasi atau yang sering dengan istilah media animasi pada dasarnya mempunyai prinsip yang sama dengan alat peraga. Penanaman konsep dengan media animasi seperti contoh di atas tidak berbeda dengan halnya ketika guru menggunakan alat peraga dengan benda nyata kelereng atau kertas. Pada alat peraga benda yang digunakan sebagai alat peraga adalah benda riil atau nyata, sedangkan pada media animasi adalah maya.

Media animasi yang didesain menggunakan software aplikasi komputer efektif digunakan dalam proses pembelajaran, karena setiap gerak animasi dari objek, gambar, teks dan lainnya sebagai wujud dari penyampaian atau penanaman konsep itu sendiri. Bahkan guru tidak harus berbicara banyak untuk menerangkan materi di kelas jika animasi pergerakan disertai dengan rekaman suara guru yang memberikan penjelasan dari setiap gerakan animasi.

Keunggulan dari media animasi dinyatakan oleh beberapa pendapat berikut. Media animasi merupakan tampilan gabungan dari unsur gambar, teks, grafik dalam suatu aktivitas gerakan animasi sehingga membuat proses pembelajaran menjadi lebih menarik (Suryanta dkk, 2014). Kemudian Mayer dan Moreno (2002: 88) mengemukakan bahwa animasi merupakan suatu bentuk presentasi bergambar yang paling menarik, yang berupa simulasi gambar bergerak yang menggambarkan perpindahan atau pergerakan suatu objek. Sukiyasa dan Sukoco (2013: 129) menyatakan penggunaan animasi dalam proses pembelajaran sangat membantu dalam meningkatkan efektifitas dan efisiensi proses pengajaran, serta hasil pembelajaran yang meningkat

Penggunaan media animasi tidak hanya dapat menanamkan konsep dasar matematika, tapi juga membuat proses pembelajaran menjadi lebih menarik. Selain itu pula inovasi pembelajaran atau ide-ide pengembangan pembelajaran lebih lebih mudah dilakukan. Perubahan-perubahan pada animasi pembelajaran atau penambahan-penambahan bentuk animasi cukup hanya dengan membuka kembali software aplikasi yang digunakan.

Dengan berbagai kemudahan dan kelebihan dari media animasi yang dibuat dengan menggunakan software aplikasi, maka media pembelajaran ini dapat dijadikan sebagai alternatif pengganti alat peraga yang bisa digunakan oleh guru untuk menanamkan pemahaman konsep dasar matematika yang dapat menjangkau kemampuan memproses informasi dalam bentuk tujuh kecerdasan yang dinyatakan Gardner (1983), yaitu 1) Logis-Matematis, 2) Spasial, 3) Linguistik, 4) Kinestetik-Keperagaan, 5) Musik, 6) Interpersonal, dan 7) Intrapersonal. Dan 
media yang dapat mengakomodir ketentuan-ketentuan tersebut adalah komputer dengan berbagai aplikasinya.

\section{Pemilihan software aplikasi pembuat animasi}

Terdapat berbagai pilihan software aplikasi dengan fasilitas pembuatan animasi yang tersedia yang bisa digunakan oleh guru. Kriteria pemilihan software yang dapat digunakan oleh guru ditentukan dengan keadaan guru itu sendiri, seberapa banyak guru mengetahui, memahami, menguasai dan memiliki skill penggunaan IT dan software aplikasi.

Pada umumnya guru tidak begitu menguasai banyak aplikasi, dan umumnya pula guru sudah terbiasa atau familiar dengan software tertentu yang sering kali digunakan. Maka kriteria pemilihan software lebih ditekankan pada software yang sederhana atau tidak rumit digunakan dan memiliki tampilan menu yang sudah sangat familiar digunakan.

Beberapa software bisa digunakan oleh guru, salah satunya Microsoft Power Point. Software aplikasi Microsoft PowerPoint merupakan salah satu software yang memiliki fasilitas pembuatan animasi. Tampilan menu sudah sangat familiar digunakan oleh para guru, karena umumnya sudah terbiasa menggunakan aplikasi Microsoft lainnya seperti Microsoft Word dan Microsoft Excel. Bahkan para guru sudah terbiasa pula menggunakan Microsoft power point, dan umumnya pula para guru tidak familiar dengan penggunaan fasilitas animasi.

Secara sederhana fasilitas pembuatan animasi pada Microsoft Power Point dapat diperlihatkan pada gambar berikut.

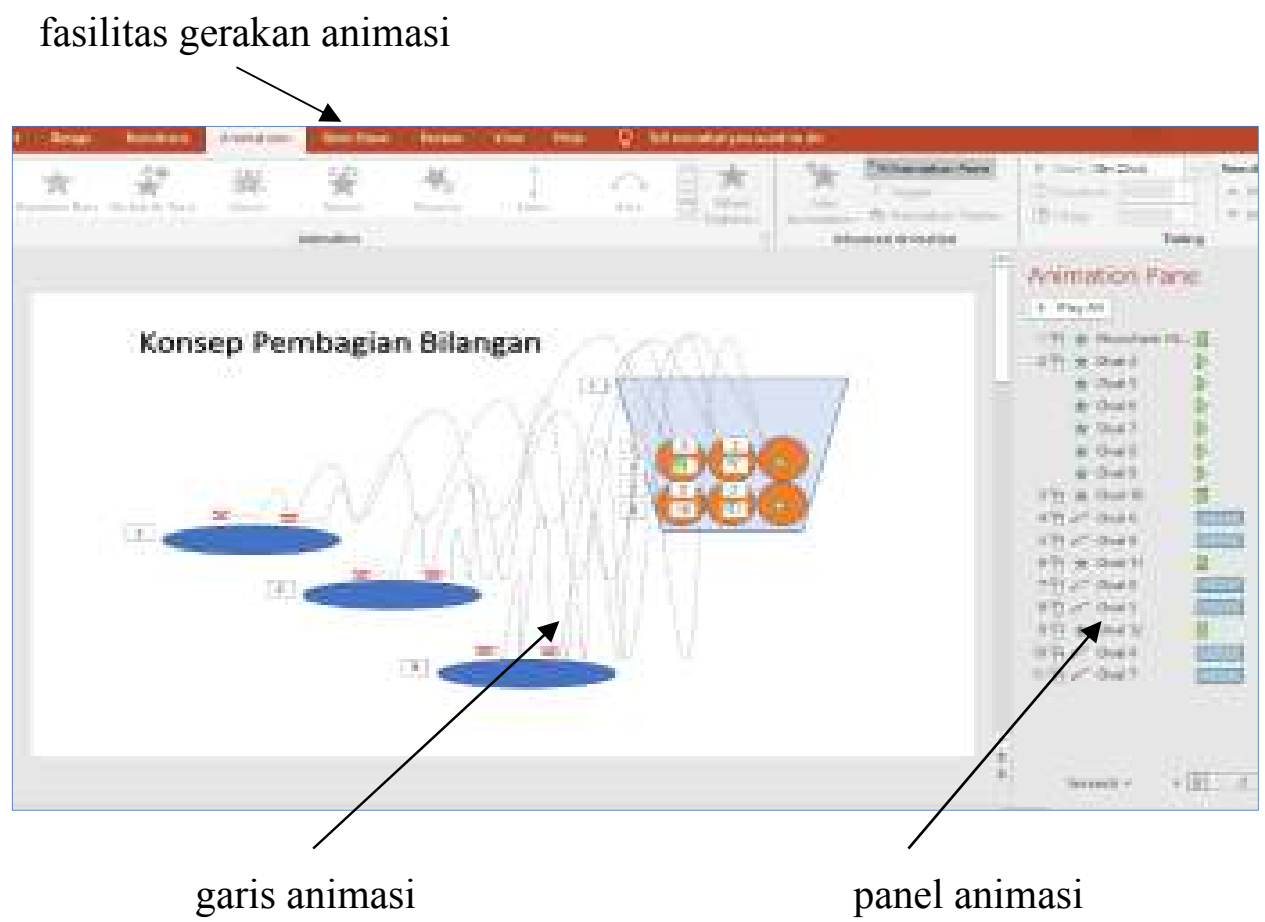

Gambar 4. Pembuatan animasi konsep pembagian bilangan dengan aplikasi MS Power Point 
Gerakan animasi yang tersedia pada power point antara lain yaitu entrance untuk memasukkan objek pada layar/slide, emphasis untuk merubah objek, motion part untuk menggerakkan objek dan exit untuk mengeluarkan objek dari layar.

\begin{tabular}{|c|c|c|}
\hline \multicolumn{2}{|l|}{ Add Entrance Effect } & $\times$ \\
\hline \multicolumn{2}{|l|}{ Basic } & $\wedge$ \\
\hline$\star$ Appear & $\star$ Blinds & \\
\hline$\star$ Box & $\downarrow$ Checkerboard & \\
\hline$\star$ Circle & $\star$ Diamond & \\
\hline$\star$ Dissolve In & $\star$ Fly ln & \\
\hline$\star$ Peek ln & $\star$ Plus & \\
\hline$\star$ Random Bars & $\star$ Split & \\
\hline$\star$ Strips & $\star$ Wedge & \\
\hline$\star$ Wheel & $\star$ Wipe & \\
\hline \multicolumn{3}{|l|}{ Subtle } \\
\hline$\star$ Expand & $\star$ Fade & \\
\hline$\star$ Swivel & $\star$ Zoom & \\
\hline \multicolumn{2}{|l|}{ Moderate } & \\
\hline$\star$ Basic Zoom & $\star$ Center Revolve & \\
\hline$\star$ Compress & $\star$ Float Down & \\
\hline$\star$ Float Up & $\downarrow$ Grow \& Turn & \\
\hline$\star$ Rise Up & $\star$ Spinner & \\
\hline$\star$ Stretch & & $\checkmark$ \\
\hline
\end{tabular}

\begin{tabular}{|c|c|c|}
\hline Add Motion Path & $?$ & X \\
\hline Basic & & $\wedge$ \\
\hline$\Leftrightarrow 4$ Point Star & W 5 Point Star & \\
\hline$\sum^{\pi} 3$ Point Star & (1) 8 Point Star & \\
\hline Circle & $\mathbb{C}$ Crescent Moon & \\
\hline$\curvearrowright$ Diamond & $\triangle$ Equal Triangle & \\
\hline$\bigcirc$ Football & $\odot$ Heart & \\
\hline 2) Hexagon & Octagon & \\
\hline$\square$ Parallelogram & $\triangle$ Pentagon & \\
\hline$\triangle$ Right Triangle & $\square$ Square & \\
\hline 8 Teardrop & $\triangle$ Trapezoid & \\
\hline \multicolumn{2}{|l|}{ Lines_Curves } & \\
\hline$\cup$ Arc Down & C Arc Left & \\
\hline J Arc Right & $\curvearrowright \operatorname{Arc} U p$ & \\
\hline or Bounce Left & $m$ Bounce Right & \\
\hline (6) Curvy Left & (2) Curvy Right & \\
\hline mo Decaying Wave & Diagonal Down Right & \\
\hline / Diagonal Up Right & 【 Down & \\
\hline 冒 Funnel & $m / p$ Heartbeat & $\checkmark$ \\
\hline
\end{tabular}

\begin{tabular}{|c|c|}
\hline Add Emphasis [ffect. & $x$ \\
\hline \multicolumn{2}{|l|}{ Dasic } \\
\hline Fill Colom & A Forr Cinleir \\
\hline \# Grow/Shriak & * Lire Color \\
\hline * 5pin & * Trscosprency \\
\hline \multicolumn{2}{|l|}{ Solitio: } \\
\hline B. Dolit Fosh & * Irvasn Coisr \\
\hline * Compiemertary Colee & * Complementay Coior 2 \\
\hline * Lontrasting Color & * Darben \\
\hline A Sesatifatu & * Lighten \\
\hline * Ityert foilar & \& Puke \\
\hline B thatelian & \\
\hline \multicolumn{2}{|l|}{ Moderate } \\
\hline * Color Pulse & A Goow With Coic \\
\hline * Shimmer & * Teeter \\
\hline \multicolumn{2}{|l|}{ Fkriting } \\
\hline A Blenk & B ilold flecosati \\
\hline + whe & \\
\hline
\end{tabular}

\begin{tabular}{|c|c|c|}
\hline Add Exit Effect & ? & $\times$ \\
\hline Basic & & $\wedge$ \\
\hline$\neq$ Blinds & ]$\star B o x$ & \\
\hline$\star$ Checkerboard & $\star$ Circle & \\
\hline$\star$ Diamond & $\star$ Disappear & \\
\hline$\star$ Dissolve Out & $\star$ Fly Out & \\
\hline$\star$ Peek Out & $\star$ Plus & \\
\hline \ Random Bars & $\star$ Split & \\
\hline$\star$ Strips & $\star$ Wedge & \\
\hline$\star$ Wheel & $\star$ Wipe & \\
\hline \multicolumn{3}{|l|}{ Subtle } \\
\hline$\star$ Contract & $\star$ Fade & \\
\hline$\star$ Swivel & $\star$ Zoom & \\
\hline \multicolumn{3}{|l|}{ Moderate } \\
\hline$\star$ Basic Zoom & $\star$ Center Revolve & \\
\hline$\star$ Collapse & $\star$ Float Down & \\
\hline$\star$ Float Up & $\star$ Shrink \& Turn & \\
\hline$\star$ Sink Down & \ Spinner & \\
\hline$\downarrow$ Stretchy & & $\checkmark$ \\
\hline
\end{tabular}

Gambar 5. Fasilitas dari MS Power Point untuk berbagai macam bentuk animasi gerakan atau perubahan yang bisa diterapkan pada berbagai objek 
Selain itu pula tersedia fasilitas untuk membuat slide master, hyper link dan penambahan unsur suara, musik dan video bahkan untuk merekam suara dan merekam layar.
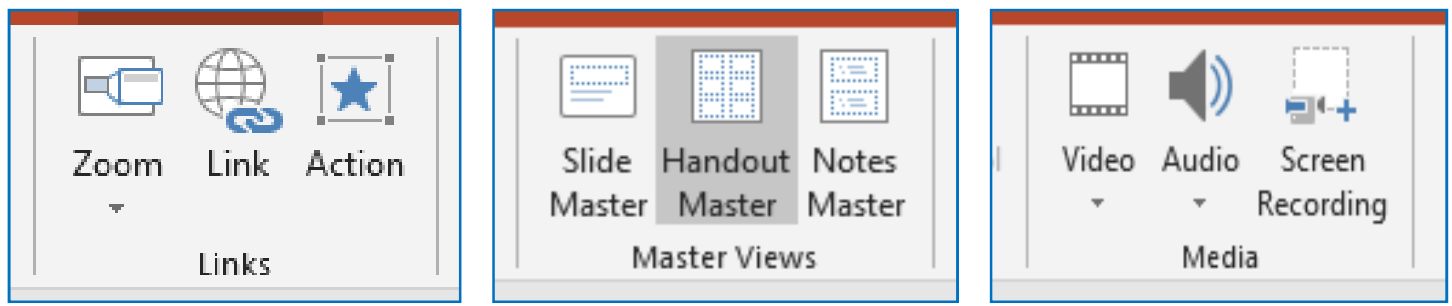

Gambar 6. Beberapa fasilitas lain yang mendukung pembuatan animasi

Dengan berbagai fasilitas untuk membuat bermacam bentuk animasi yang disertai dengan tambahan unsur suara atau musik, dan software ini juga sangat familiar digunakan karena sebagian menu lainnya sudah dikenali lewat software Microsoft lainnya antara lain; Microsoft Word atau Microsoft Excel, maka software aplikasi ini dapat dijadikan sebagai alternatif pembuat media pembelajaran berbentuk animasi.

\section{SIMPULAN DAN SARAN}

Penyajian konsep dasar matematika pada peserta didik khususnya di tingkat sekolah dasar perlu mendapatkan perhatian dan kecermatan yang baik oleh para guru, sehingga pemahaman konsep yang diterima oleh siswa tidak keliru. Penanaman konsep dasar matematika merupakan hal yang sangat vital, karena matematika merupakan ilmu dasar yang menjadi alat untuk mempelajari ilmu pengetahuan yang lain untuk terus selanjutnya digunakan ke jenjang pendidikan yang lebih tinggi.

Media pembelajaran berbentuk animasi merupakan media yang efektif untuk menanamkan konsep dasar matematika sebagai alternatif pengganti dari alat peraga yang sering digunakan. Berbagai keunggulan dan kelebihan media animasi adalah lebih mudah melakukan inovasi pembelajaran karena desain animasi yang mudah diubah dengan membuka lagi software aplikasi, pengajaran lebih menarik karena tampilan gerakan animasi yang disertai unsur suara dan musik, waktu penyampaian materi lebih singkat dan pengajaran dapat dilakukan kapan dan dimana diinginkan karena media animasi adalah media dalam bentuk software bukan dalam bentuk barang atau peralatan, selain itu pula media animasi dapat mengubah peran positif guru, karena guru tidak harus memperagakan langsung dan rekaman suara dapat dibuat terlebih dahulu sebelum disampaikan ke peserta didik.

Pemilihan software aplikasi juga menjadi hal penting untuk dapat dikuasai oleh para guru dengan memperhatikan beberapa kriteria antara lain yaitu kesederhanaan dan menu yang familiar.

\section{DAFTAR PUSTAKA}

Andesta, E. D., Rahmi, dan Harisman, Y. 2013. Pengaruh Penerapan Pembelajaran Aktif Tipe Questions Students Have (QSH) Terhadap Pemahaman Konsep Matematis Siswa Kelas VIII SMPN 1 Pasaman. Jurnal Mahasiswa Prodi Pendidikan Matematika Publisher: STKIP PGRI Sumbar. 
Asnawir dan Usman, B. 2002. Media pembelajaran. Jakarta: Ciputat Pers.

Asyhar, Rayanda. 2011. Kreatif Mengembangkan Media Pembelajaran. Jakarta: Gaung Persada (GP) Press Jakarta.

Dahlan, J.A., 2004. Meningkatkan Kemampuan Penalaran dan Pemahaman Matematika Siswa Sekolah Lanjutan Tingkat Pertama Melalui Pendidikan Pembelajaran Open-ended, Studi Eksperimen pada Siswa Sekolah Lanjutan Tingkat Pertama Negeri di Kota Bandung. Disertasi tidak diterbitkan. Bandung: PPD UPI.

Depdiknas. 2003. Pedoman Khusus Pengembangan Sistem Penilaian Berbasis Kompetensi SMP. Jakarta: Depdiknas.

Effendi, Zakaria, dkk. 2007. Trend Pengajaran dan Pembelajaran Matematik. Kuala Lumpur: Utusan Publications dan Distributors SDN BHD.

Gardner, H. 1983. Frames of mind - The theory of multiple intelegences. New York: Basic Books Inc.

Lestari, Linda Puji. 2006. Keefektifan Pembelajaran dengan Menggunakan Alat Peraga dan LKS. [Online]. Tersedia: http://digilib.unnes.ac.id.skripsi/archives/doc.pdf. [15 Desember 2019].

Maharani, Isma Nastiti. 2017. Model Pengembangan Bahan Ajar Matematika Untuk Sekolah Dasar. Vox Edukasi, Jurnal Ilmiah Ilmu Pendidikan, Vol. 8(1) : 1-10. [Online]. Tersedia : http://jurnal.stkippersada.ac.id/jurnal/index.php/VOX/ article/view/54/51.

Murizal, Angga. 2012. Pemahaman Konsep Matematis dan Model Pembelajaran Quantum Teaching. Jurnal Pendidikan Matematika, Vol. 1(1) : 19-23. [Online]. Tersedia : https://adoc.tips/pemahaman-konsep-matematis-danmodel-pembelajaran-quantum-te.html

Mayer, R. E. and Moreno, R. 2002. Animation as an Aid Multimedia Learning. Educational Psychology Review, Vol. 14(1), March 2002. [Online]. Tersedia: https://link.springer.com/article/10.1023/A:1013184611077. [15 Desember 2019].

Prihandoko, Antonius Cahya. 2006. Memahami Konsep Matematika Secara Benar dan Menyajikannya dengan Menarik. Jakarta: Depdiknas.

Ruseffendi, H. E. T. 2006. Pengantar kepada Membantu Guru Mengembangkan Kompetensinya dalam Pengajaran Matematika untuk Meningkatkan CBSA. Bandung: Tarsito.

Sagala, S. 2008. Konsep dan Makna Pembelajaran. Bandung: Alfabeta.

Sardiman. 2010. Interaksi \& Motivasi Belajar Mengajar. Jakarta: Rajawali Pers.

Shadiq, Fadjar. 2004. Pemecahan Masalah, Penalaran, dan Komunikasi. Makalah disampaikan pada Diklat Instruktur/Pengembang Matematika SMP Jenjang Dasar di PPPG Matematika tanggal 6 s.d. 19 Agustus 2004. Yogyakarta : Depdiknas Dirjendiknas Dasar dan Menengah Pusat Pengembangan Penataran Guru (PPPG) Matematika Yogyakarta.

Simanjuntak, Lisnawaty dkk. 1990. Metode Mengajar Matematika. Jakarta: Rineka Cipta.

Soedjadi. 2000. Kiat Pendidikan Matematika di Indonesia. Bandung: Dirjen Dikti Depdiknas.

Somayasa, W., Natajaya, N., dan Candiasa, M. 2013. Pengembangan Modul Matematika Realistik Disertai Asesmen Otentik Untuk Meningkatkan Hasil Belajar Matematika Peserta Didik Kelas X di SMK Negeri 3 Singaraja. e- 
Journal Program Pascasarjana Universitas Pendidikan Ganesha, Vol. 3. [Online]. Tersedia : https://media.neliti.com/media/publications/207272pengembangan-modul-matematika-realistik.pdf.

Sukiyasa, K. dan Sukoco. 2013. Pengaruh Media Animasi Terhadap Hasil Belajar dan Motivasi Belajar Siswa Materi Sistem Kelistrikan Otomotif. Jurnal Pendidikan Vokasi, Vol. 3(1) : 126-137. [Online]. Tersedia : https://journal.uny.ac.id/index.php/jpv/article/view/1588/1318. [31 Desember 2019].

Sundayana, R. 2016. Media dan Alat Peraga dalam Pembelajaran Matematika. Bandung: Alfabeta.

Suryanta, Made., Abadi, Ida B.G., dan Asri, A. S. 2014. Pengaruh Model Pembelajaran Scramble Berbantuan Media Animasi Terhadap Hasil Belajar IPA Siswa Kelas V SD Gugus Yos Sudarso Denpasar. Jurnal Mimbar PGSD Universitas Pendidikan Ganesha, Vol. 2(1). [Online]. Tersedia : https://ejournal.undiksha.ac.id/index.php/JJPGSD/article/view/2209

Sutawijaya, A dan Afgani, J. 2011. Pembelajaran Matematika. Jakarta: Universitas Terbuka. 